\title{
Optimization of exopolysaccharides production by Bacillus subtilis
}

\author{
M.I. Abou-Dobara ${ }^{\mathrm{a}}$, A.A. El-Fallal ${ }^{\mathrm{a}}$, E. Toson ${ }^{\mathrm{b}}$, A. Abbas ${ }^{\mathrm{c}}$, F. El-Feky ${ }^{\mathrm{a}}$ \\ a Department of Botany, Faculty of Science, Damietta University, Egypt \\ ${ }^{\mathrm{b}}$ Department of Chemistry, Faculty of Science, Damietta University, Egypt \\ ${ }^{\mathrm{c}}$ Gastroenrology Center, Mansoura University, Mansoura, Egypt
}

Received: 21 September 2013 / Accepted: 11 December 2013

*Corresponding author (Tel: +20.01224704250; Fax: +20.57.2403868, email: aboudobara@ du.edu.eg)

\begin{abstract}
The environmental and nutritional parameters were studied aiming to give a maximal exopolysaccharides (EPS) production by Bacillus subtilis. The basal medium (BM) was appeared to be the optimum medium among the seven tested media at $150 \mathrm{rpm}$. The highest production of EPS was obtained after 3 days incubation period, $\mathrm{pH} 7.0$ and $25^{\circ} \mathrm{C}$. Sucrose was the best carbon source stimulating the maximum production of EPS followed by mannitol. The maximum production was achieved at concentration $4.5 \%$ of sucrose. The highest production of EPS was recorded by using yeast extract with a concentration of $0.22 \%$.
\end{abstract}

Keywords: optimization, exopolysaccharides, production, Bacillus subtilis

\section{Introduction}

Polysaccharides are a highly diverse group of polymers, of which the functional features are determined by their structural characteristics that may differ in molecular weight, saccharide linkage type, degree of branching and chemical composition [1]. This diversity led to broad applications in industry. Most of the polysaccharides used in the food industry as thickener, stabiliser, texturizing and gelling agents are derived from plant (e. g. starch, pectin, gum arabic) or seaweeds (e. g. alginate, carrageenan). In the last decades several microbial exopolysaccharides (EPS) have been described as alternatives for plant polysaccharides. Microbial polysaccharides have rheological properties that match the technological demands and can be produced in large amounts and high purity. Microbial polysaccharides can be divided based on their location into (i) capsular polysaccharides (CPS) associated with the cell surface, and believed to belong to the virulence characteristics of pathogens (Streptococcus penumoniae), and (ii) extracellular polysaccharides (EPS) secreted in the environment of the cell. It is suggested that CPS play a role in protection of microbial cells against desiccation, phagocytosis, phage attack, antibiotics and toxic compounds, and provide the cell with the capability to adhere to solid surfaces [2].

The ability of EPS production is widely spread among bacteria and less among yeasts and 
fungi [3]. In the last years several EPS producing lactobacilli were described. Most of these lactobacilli were isolated from dairy products e. g. fermented milk, yoghurts and kefir grains [4]. EPS seem not to serve as nutrient reserve, since the most EPS producing bacteria are not able to degrade the EPS they produce [5]. Based on their composition EPS can be classified into homoand heteropolysaccharides. Homopolysaccharides consist of one monosaccharide (mostly fructose or glucose), and are usually produced in large amount from sucrose by the action of glycansucrases [6].
Heteropolysaccharides are mostly composed of identical repeating units consisting of two or more monosaccharides e. g. galactose, glucose, rhamnose and fructose (Table 1). Several linkages can occur at the same time in one polysaccharide. Heteropolysaccharides are produced intracellulary as subunits and usually in small amounts up to $1.5 \mathrm{~g} \mathrm{l}^{-1}$. Sugar nucleotides play an essential role in the synthesis of heteropolysaccharides due to their function in sugar interconversions as well as sugar activation [5].

Table 1. Overview of some heteropolysaccharides producing bacteria

\begin{tabular}{lll}
\hline EPS & Trivial name & Producing microorganism \\
\hline a-glucan & Dextran & \\
& Mutan & Leuconostoc mesenteroides \\
& Pullulan & Streptococcus mutans \\
B-glucan & Fructan & Aureobasidium pullulans \\
& Cellulose & Lactobacillus sanfranciscensis \\
Fructan & Curdlan & Acetobacter xylinum \\
& Levan & Alcaligenes sp., Rhizobium $\mathrm{sp}$. \\
& Inulin & Streptococcus salivarius \\
Polygalactan & Fructan and glucan & Streptococcus mutans \\
& Polygalactan & Lactobacillus reuteri \\
& & Lactococcus lactis sp. cremoris \\
\hline
\end{tabular}

Dextran synthesized by $L$. mesenteroides was one of the first biopolymers produced on industrial scale in 1948 [7] and was found several applications in medicine, separation technology and biotechnology [8]. Xanthan from Xanthomonas campestris and gellan (Gelrite) from Sphingomonas paucimobilis are also produced in large amounts and have found various food and non-food applications [3]. The interest of the food industry in developing "multifunctional additives", that not only provide the desired improvement of the texture but also have additional nutritional properties, led to extensive search for polysaccharides with prebiotic attributes. Prebiotics are non-digestible food ingredients that affect the host beneficially by selectively stimulating the growth and/or activity of one or a limited number of bacteria in the colon and thus improve host health [9]. Fructo- oligosaccharides (FOS), xylooligosaccharide and inulin are some prebiotics available for the human consumption [10] . FOS with prebiotic properties (e. g. kestose, nystose) are polymers of D-fructose joined by $\beta(2 \rightarrow 1)$ linkages and terminated with a Dglucose molecule linked to fructose by an $\alpha(1 \rightarrow 2)$ bond as in sucrose [11]. The degree of polymerization (DP) can vary from 2-35. FOS with DP of 3-5 are called neosugars [12] and are enzymatically synthesized from sucrose using fructosyltransferase obtained from Aspergillus niger [13]. Mckellar and Modler showed that the maximum activity of $B$-fructosidase responsible for the hydrolysis of inulin type polysaccharides by bifidobacteria was observed with neosugars [14].

Role of polysaccharide to the producing bacterium

The production of exopolysaccharides is a significant energy cost to bacteria, and yet direct observation of bacterial cells in a wide variety of natural and industrial environments show, unequivocally, that all such cells are surrounded by structured exopolysaccharides and that many produce very large amounts of extracellular glycocalyx material.

Ecological studies of bacterial growth in natural systems have discovered certain pattern or strategies that used by bacteria in whatever environment they find themselves. Unlike test 
tube bacteria, wild strains produce large amounts of exopolysaccharide and they use this external component to colonize specific surfaces, to mediate specific associations with other bacteria and with tissues, to produce the matrix of a protective biofilm, and to trap and concentrate nutrients from flowing fluids. In ecosystems with a finite supply of nutrients, these molecules are adsorbed and metabolized by bacteria within adherent biofilms until starvation overtakes any cells that penetrate past this nutrient rich zone. These starved cells reduce their cell size and their polysaccharide production and remain as minute, non adherent propagules until they encounter sufficient concentrations of nutrients to resume normal metabolic activity [15].

The aim of the present work was to optimize exopolysaccharide production by Bacillus subtilis.

\section{Materials and methods}

\section{Isolation and identification of isolated bacterium}

Isolated species of bacterium was identified using growth characteristics and various physiological and biochemical activities according to Bergey`s Manual of Systematic Bacteriology [16] and The Procaryotes [17].

\section{Growth and maintenance of bacterial strains}

Bacterial strains were maintained and routinely cultured on nutrient agar medium that has the following composition $\left(\mathrm{g} \mathrm{l}^{-1}\right)$ : beef extract, 3; peptone, 5; agar, 20; dist. water, $1 \mathrm{~L}$ and the $\mathrm{pH}$ was adjusted to 7.0. The inoculated media were incubated at $30^{\circ} \mathrm{C}$ for 24 hours.

\section{Screening of exopolysaccharides production by bacteria}

Exopolysaccharide screening of the bacterial strains was carried out on the solid basal media containing either glucose or sucrose $\left(20 \mathrm{~g} \mathrm{l}^{-1}\right)$ as a carbon source. Basal medium (BM) contains the following gradients per 1 liter distilled: yeast extract 0.5.; $\mathrm{CaCl}_{2}$ 0.05; $\left(\mathrm{NH}_{4}\right)_{2} \mathrm{SO}_{4} 0.6 ; \mathrm{KH}_{2} \mathrm{PO}_{4}$ 3.18; $\mathrm{K}_{2} \mathrm{HPO}_{4} 5.2 ; \mathrm{MgSO}_{4} \cdot \mathrm{H}_{2} \mathrm{O} 0.3 ; \mathrm{FeSO}_{4} .7 \mathrm{H}_{2} \mathrm{O}$ $0.0006 ; \quad \mathrm{ZnSO}_{4} .7 \mathrm{H}_{2} \mathrm{O} \quad 0.0002 ; \quad \mathrm{CuSO}_{4} .5 \mathrm{H}_{2} \mathrm{O}$ $0.0002 ; \mathrm{MnSO}_{4} \cdot \mathrm{xH}_{2} \mathrm{O} \quad 0.0002 ; \mathrm{CoCl}_{2} .6 \mathrm{H}_{2} \mathrm{O}$ 0.0002; agar 20. The $\mathrm{pH}$ was adjusted to 7.0.

The bacteria were grown on agar plates at 30 $\pm 1^{\circ} \mathrm{C}$ for 3 days and the plates were visually inspected for slime production.

Single spore cultures of the bacterial strains were grown on nutrient agar slopes at $30^{\circ} \mathrm{C}$ for 24 hours, and suspension of the investigated bacteria were used to inoculate flasks containing exopolysaccharide liquid basal medium (50) $\mathrm{ml}$. The culture was incubated at $30 \pm 1{ }^{\circ} \mathrm{C}$ at 150 rev. $\mathrm{min}^{-1}$ on rotary incubator shaker for 24 hour. Production flasks were then inoculated using 6\% inoculum (24-h seed culture). The bacterial growth was measured using Turbidity meter.

The bacteria were routinely grown in conical flask $(250 \mathrm{ml})$ containing liquid basal exopolysaccharide medium that has sucrose as carbon source $\left(20 \mathrm{~g} \mathrm{l}^{-1}\right)$. The $\mathrm{pH}$ of the liquid medium was initially adjusted to 7.0 before autoclaving. After inoculation, cultures were incubated at $30^{\circ} \mathrm{C}$ with shaking at 150 rev. $\mathrm{min}^{-1}$ for 3 days.

\section{Extraction of exopolysaccharides (EPS) from bacteria}

After the incubation period, the cultures were harvested by centrifugation at $10000 \mathrm{rpm}$ for 45 min. at $4^{\circ} \mathrm{C}$ using a microcentrifuge (Denver Instrument Microcentrifuge). Culture supernatants were used in precipitating exopolysaccharides. The EPS was precipitated from the supernatant by addition of four volume of $95 \%(\mathrm{v} / \mathrm{v})$ aqueous ethyl alcohol. The mixture was agitated during addition of alcohol to prevent local high concentration of the precipitate, and the resulting solution was kept at $4{ }^{\circ} \mathrm{C}$ overnight before being centrifuged at $7000 \mathrm{rpm}$ for $20 \mathrm{~min}$. The precipitate was collected and dried at $80{ }^{\circ} \mathrm{C}$ to constant weight.

Factors affecting the exopolysaccharides production by Bacillus subtilis on submerged culture

Factors affecting exopolysaccharide (EPS) and biomass production by Bacillus subtilis were studied using shaking flask culture on rotary incubator shaker at $150 \mathrm{rev} . \mathrm{min}^{-1}$ and $30 \pm 1{ }^{\circ} \mathrm{C}$ in $250 \mathrm{ml}$ flask containing $50 \mathrm{ml}$ medium. A standard inoculum was used to inoculate a $50 \mathrm{ml}$ medium (2 ml $50 \mathrm{ml}^{-1}$ media). Both dry weight of EPS and biomass were determined.

Studies on exopolysaccharides production using different types of media were carried out. Seven different types of media including BM medium (namely Yeast extract-malt extract 
(YEME) medium, Sabaroud dextrose broth (SD), Yeast extract, peptone, glucose (YPM) medium, Yeast extract-glucose (YG) medium, Nutrient broth glucose (NBG) and Xanthan production (XP) medium). The $\mathrm{pH}$ was adjusted to 7.15. Unless otherwise stated $160 \mathrm{mM}$ sucrose and $0.125 \%$ casein hydrolysate were added. EPS and biomass in each type of media were determined.

Effect of different incubation periods on EPS production was carried out by incubating the bacterial culture on the most suitable medium for different incubation periods. EPS and biomass were determined daily for up to 7 days.

To determine the effect of $\mathrm{pH}$ values, $1 \mathrm{~N} \mathrm{HCl}$ or $1 \mathrm{~N} \mathrm{NaOH}$ were used to adjust the culture media to different $\mathrm{pH}$ ranges (from 4 to 10 ). The bacterial culture media were incubated on the most suitable medium and the most suitable period of time.

The effect of different temperatures has been studied by incubating the bacterial culture at different temperatures at 20, 25, 30, 35, 40, 45, 50 , and $55{ }^{\circ} \mathrm{C}$ using the best culture media and the most suitable period of time and $\mathrm{pH}$, the EPS and biomass were measured.

The effect of different carbon sources has been studied by addition of various sugars (i.e. galactose, glucose, sucrose, lactose, mannitol, maltose arabinose, xylose and sorbose) in weights equivalent to $2 \%$ glucose. The culture medium was adjusted to $\mathrm{pH} 7$ and incubated for 4 days period of time and $25 \pm 1{ }^{\circ} \mathrm{C}$.

The effect of different concentrations of sucrose on the EPS production was studied using concentrations $0.5,1.0,1.5,2.0,2.5,3.0,3.5,4.0$, $4.5,5.0,5.5,6.0$ and $6.5 \%$ ). The culture medium was adjusted to $\mathrm{pH} 7$ and incubated for 4 days period of time and $25 \pm 1{ }^{\circ} \mathrm{C}$. Both EPS and biomass were determined.

The effect of different nitrogen sources was studied in presence of $4.5 \%$ sucrose as carbon source. Ten different nitrogen sources (ammonium sulphate, tryptone, ammonium hydrogen phosphate, ammonium oxalate, potassium nitrate, peptone, yeast extract, ammonium nitrate and meat extract) were added with amount necessary to supply equimolecular weights of nitrogen contained in yeast extract and ammonium sulphate used in the basal medium, i.e. $0.178 \%$ nitrogen. The culture medium was adjusted to $\mathrm{pH} 7$ and incubated for 4 days period of time and $25 \pm 1{ }^{\circ} \mathrm{C}$. Both EPS and biomass were determined.

The effect of different concentrations of ammonium sulphate as the best nitrogen source was studied in which the medium was supplied with $0.02,0.07,0.12,0.17,0.22,0.27,0.32,0.37$, 0.42 and $0.47 \mathrm{~g}$ yeast extract per $100 \mathrm{ml}$ medium. The culture medium was adjusted to $\mathrm{pH} 7$ and incubated for 4 days period of time and $25 \pm 1$ ${ }^{\circ} \mathrm{C}$. Both EPS and biomass were determined.

\section{Results}

Optimization of exopolysaccharides (EPS) production by Bacillus subtilis.

The effect of different seven types of media on production of EPS by Bacillus subtilis was tested. The basal medium stimulated the EPS production and appeared to be the optimum medium among the seven tested media (Fig. $1 \mathrm{a}$ and $\mathrm{b}$ ).

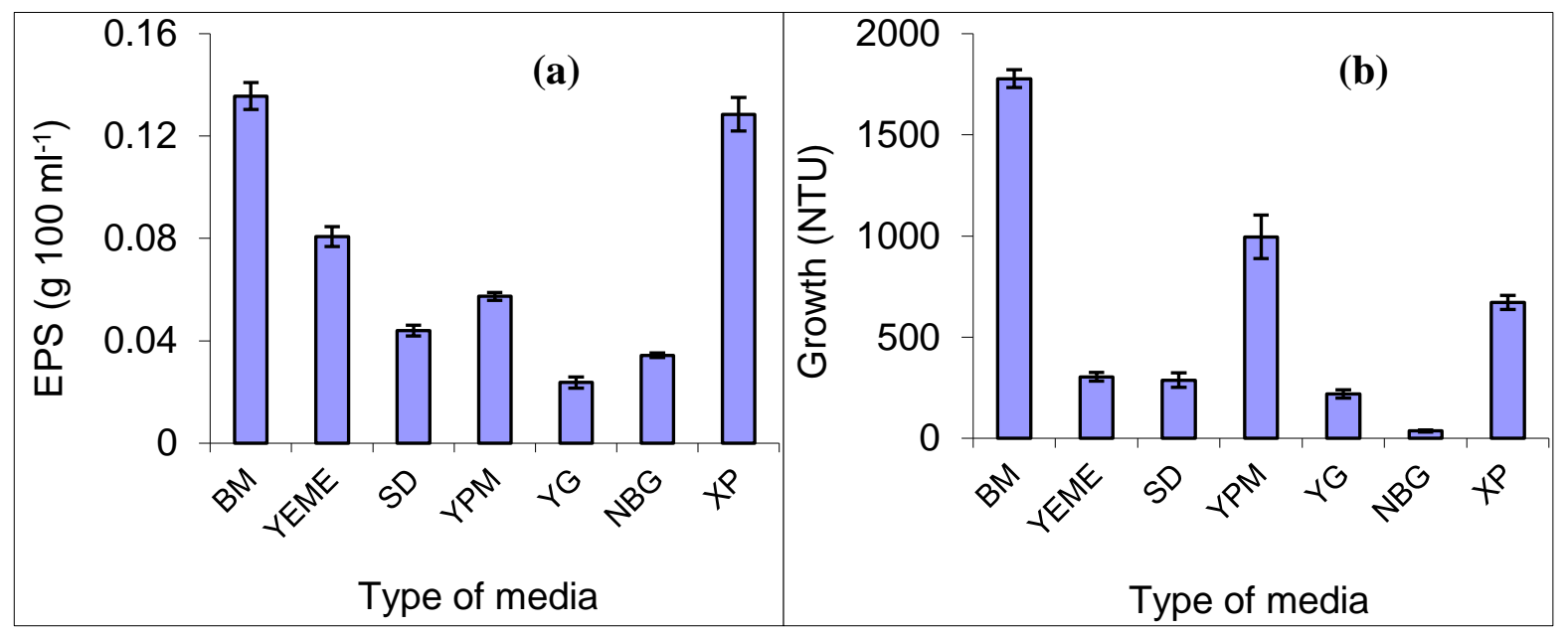

Fig. 1 Effect of medium type on exopolysaccharide (EPS) production (a) and growth (b) of Bacillus subtilis. Data are represented by means of three replica \pm SE. 
The effect of incubation period on the production of EPS and growth of Bacillus subtilis was shown in Fig. 2. The production of EPS increased during the growth phase of the culture, and the period for the maximum production was reached after 72 hours (the $3^{\text {rd }}$ day). In the $4^{\text {th }}$ day the production of EPS declined gradually, and then reached the minimum level at the end of incubation period $\left(7^{\text {th }}\right.$ day). The maximum growth of Bacillus subtilis was reached at the $3^{\text {rd }}$ day followed by stationary region through $4^{\text {th }}$ and $5^{\text {th }}$ days. There is no significant decrease in growth at decline phase which reached at 6 to 7 days.

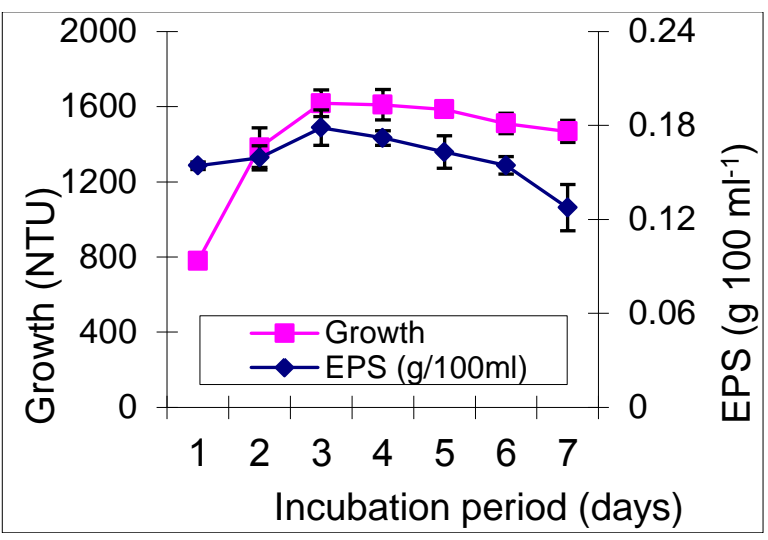

Fig. 2 Effect of incubation periods on production of EPS and biomass by Bacillus subtilus. Data are represented by means of three replica $\pm \mathrm{SE}$.

The effect of $\mathrm{pH}$ on the production of EPS was studied by adjusting the $\mathrm{pH}$ of growth medium from $\mathrm{pH} 5.0$ to $\mathrm{pH} 10.0$ (Fig. 3). EPS production increased gradually at $\mathrm{pH} 5.0$ and 6.0 and the optimum $\mathrm{pH}$ for EPS production occurred at $\mathrm{pH}$ 7.0. After that, there is a decrease in EPS level at $\mathrm{pH} 8.0$ to 10.0.

Maximum growth production by Bacillus subtilis was obtained at $\mathrm{pH} 7.0$ and then decreased gradually at $\mathrm{pH} 8.0$ to 10.0 .

The effect of a range of carbon sources on the EPS production and growth were tested and the results are shown in Fig. 4 a and b. Bacillus subtilis was able to grow in medium supplied with nine different carbon sources which were maltose, lactose, sorbose, galactose, arabinose, xylose, sucrose, glucose and mannitol. It has been found that sucrose was the best carbon source stimulating the maximum production of EPS followed by mannitol. It is appeared that there is an increase of EPS production when using sucrose comparing with all carbon sources used. At the same time there is a slight difference in production of EPS between the other carbon sources.

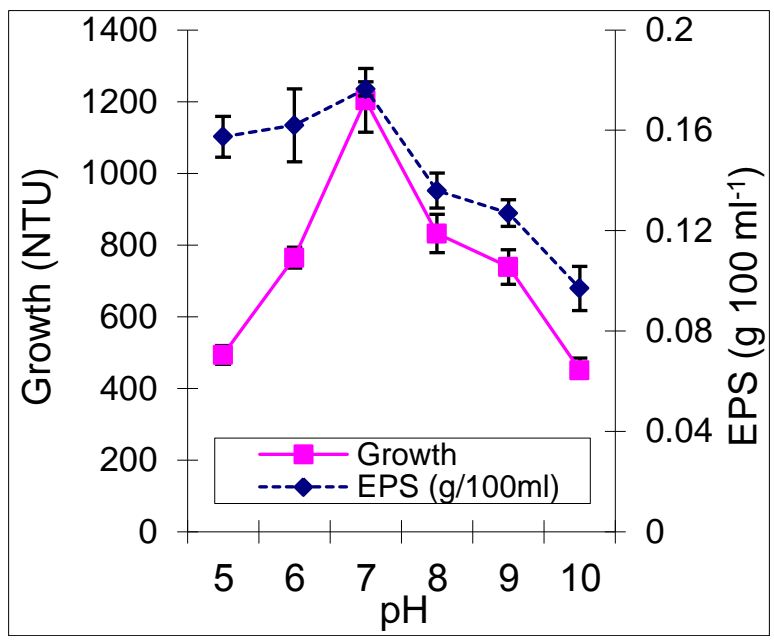

Fig. 3 Effect of different $\mathrm{pH}$ values on production of EPS and biomass by Bacillus subtilis. Data are represented by means of three replica \pm SE.

Glucose, maltose and mannitol also supported a good biomass production, but the minimum growth was obtained by sorbose.

The effect of sucrose concentration on EPS production and growth of Bacillus subtilis was shown in Fig. 5. EPS production increased with increasing the sucrose concentration until the maximum production was achieved at concentration $4.5 \%$ followed by $5.0 \%$. Above this concentration EPS production was decreased.

The biomass was increased with the increasing of the sucrose concentration with the optimum concentration reached at $5.5 \%$.

The production of EPS was tested by using ten different nitrogen sources as shown in Fig. 6 $a$ and $b$. The highest production of EPS was recorded by using yeast extract, $\mathrm{KNO}_{3}$ and peptone as nitrogen sources, respectively. Also meat extract, ammonium sulphate, ammonium sulphate plus yeast extract (AS + YE) gave low production of EPS. However, the other nitrogen sources as tryptone, $\mathrm{NH}_{4} \mathrm{NO}_{3}$, ammonium phosphate and ammonium oxalate led to minimum EPS production.

The highest production of biomass was reached when using $\mathrm{KNO}_{3}$ as nitrogen source followed by peptone and meat extract. Tryptone, 
yeast extract and $\mathrm{NH}_{4} \mathrm{NO}_{3}$ also stimulate the growth of Bacillus subtilis, respectively, however, the other nitrogen sources as ammonium sulphate plus yeast extract (AS + YE), ammonium phosphate, ammonium oxalate and ammonium sulphate slightly supported the bacterial growth.

The effect of different yeast extract concentration on the growth and production of EPS was examined and the results are shown in Fig. 7. The EPS production increased from 0.02 $\%$ up to $0.32 \%$ after which there was a gradual decline down to $0.47 \%$. Also, the growth increased from $0.02 \%$ up to the optimum at $0.22 \%$ then declined at the higher concentrations.

Table 2. Morphological characteristics of isolate no. 1.

\begin{tabular}{|c|c|c|c|c|c|}
\hline \multicolumn{3}{|c|}{ Colony } & Transparency & Pigmentation & Margin \\
\hline Shape & Consistency & Color & opaque & no & rhizoid \\
\hline \multirow[t]{2}{*}{ Irregular } & slimy & creamy & & & \\
\hline & Shape of bacteria & & End & ospore & \\
\hline Shape & Gram response & Diameter of the cell & Present & Shape & Position \\
\hline Rod & + & $<1.0 \mathrm{um}$ & + & ovoid & Central \\
\hline
\end{tabular}

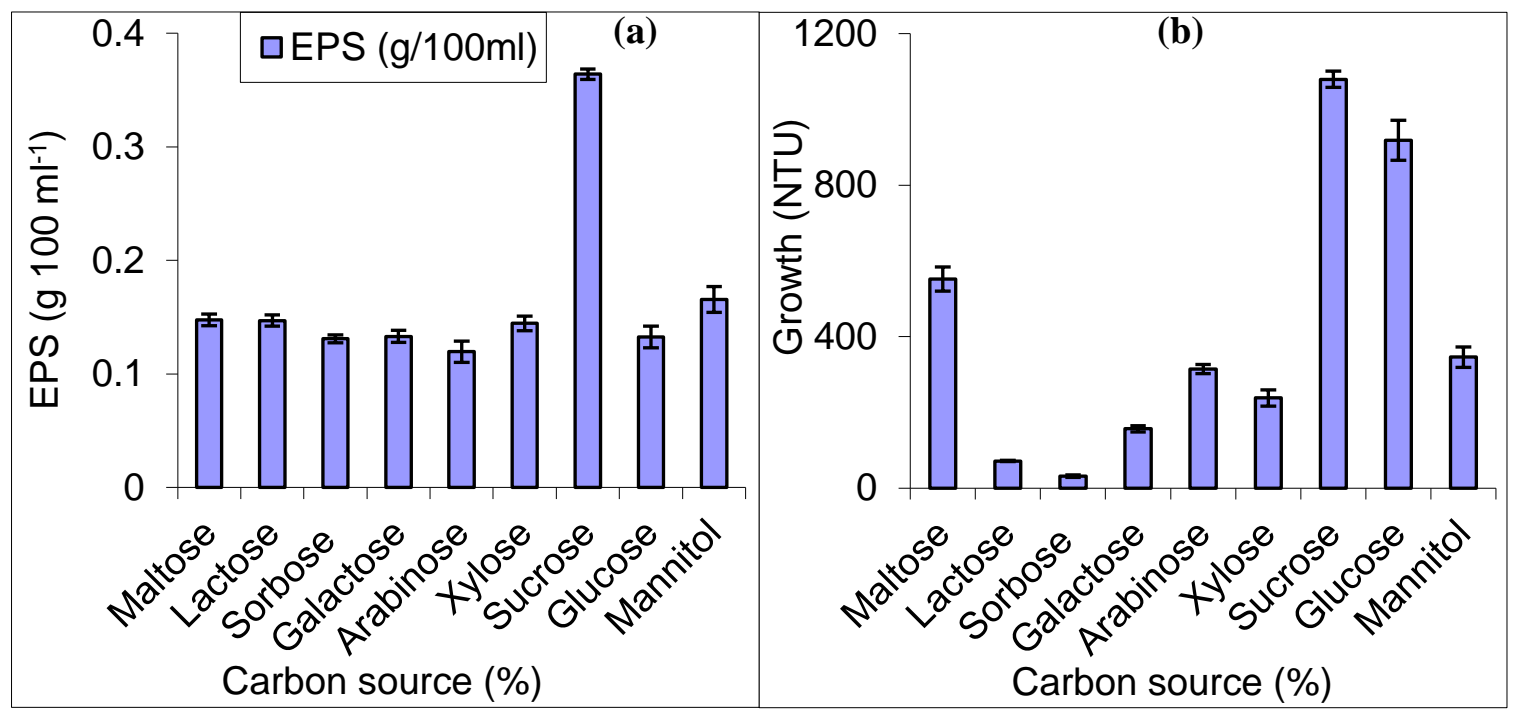

Fig. 4 Effect of different carbon sources on EPS production (a) and biomass production (b) by Bacillus subtilis. Data are represented by means of three replica \pm SE.

Characterization and identification of the selected bacterial strain growth

Agar colonies of strain no. 1 are dull, yellowish, irregular, flat, opaque, highly spreading on nutrient agar medium (Table 2).

According to the morphological and physiological studies, strain 1 indicated that it should be classified in the genus Bacillus. Following the information provided in Bergey's
Manual of systematic Bacteriology and The Procaryotes, strain 1 was closely related to Bacillus subtilis on the results stated above and could be classified as Bacillus subtilis.

Isolate no. 1 had rod-shaped cells. The cell width is less than $1.0 \mu \mathrm{m}$ and the length is about $1.0 \mu \mathrm{m}$. The isolate is Gram positive, and endospore forming and the sporangium is not swollen. Spore is spherical in shape 
and central in position (Table 2).

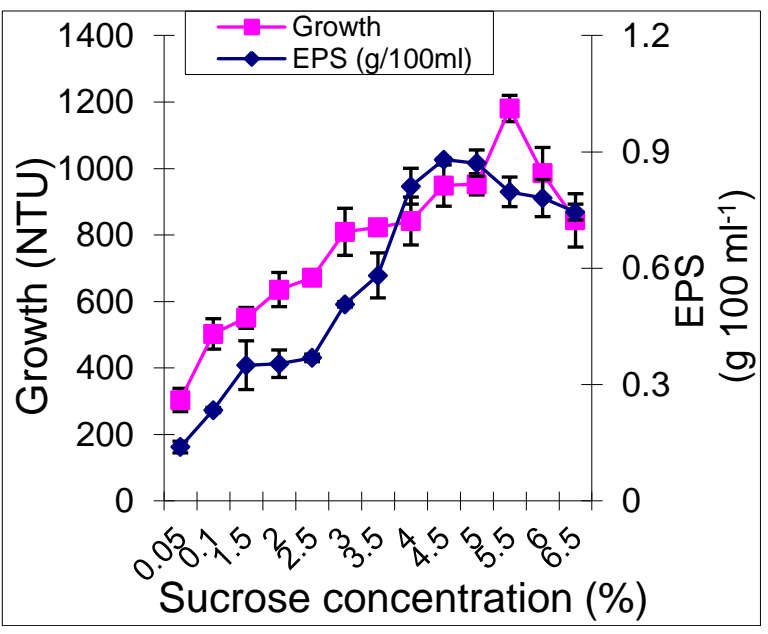

Fig. 5 Effect of sucrose concentration on production of EPS and biomass by Bacillus subtilis. Data are represented by means of three replica \pm SE.

\section{Identification}

According to the morphological and physiological studies, strain 1 indicated that it should be classified in the genus Bacillus.
Following the information provided in Bergey's Manual of systematic Bacteriology and The Procaryotes, strain 1 was closely related to Bacillus subtilis on the results stated above and could be classified as Bacillus subtilis.

\section{Discussion}

A variety of high-molecular-weight polysaccharides produced by bacteria (alginate, gellan, and xanthan) find applications as viscosifying, stabilizing, emulsifying, gelling, or water-binding agents in food and nonfood industries [2,3]. All of these polysaccharides are used as additives, however, and therefore they are considered less desirable in the food industry.

Different bacterial species produce exopolysaccharides (EPSs), located outside the cell wall, which results in mucoid, slimy colonies [18]. It is known that microbial production of EPS and sugar composition are both influenced by culture conditions. In addition, EPS production is stimulated by excess carbohydrate in the growing medium and by low temperatures [2].

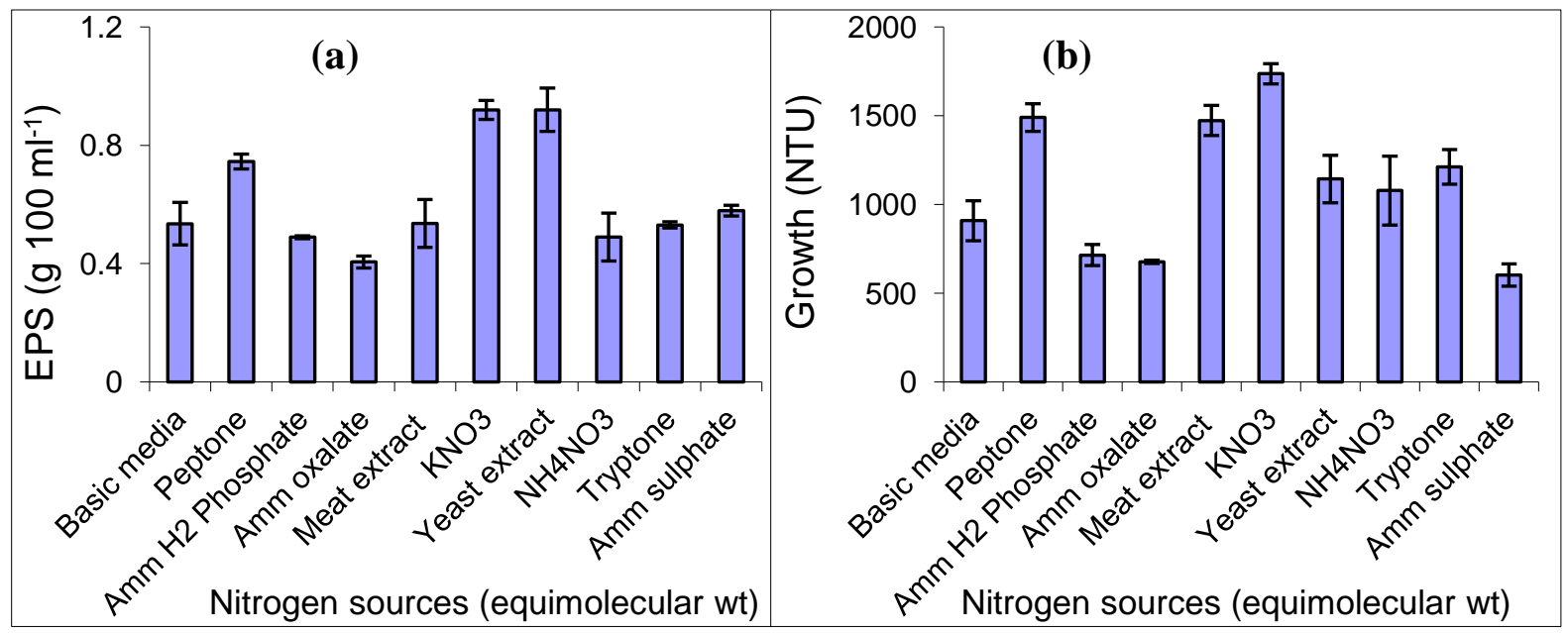

Fig. 6 Effect of different nitrogen sources on production of EPS (a) and biomass (b) by Bacillus subtilis. Data are represented by means of three replica $\pm \mathrm{SE}$.

Microbes release polysaccharides extracellularly as exopolysaccharides (EPSs) into the environment in the form of capsules or slime. Naturally occurring polysaccharides possess a unique combination of functional properties and environmentally friendly features. They are renewable in nature, nontoxic, and biodegradable
[19]. Microbial polysaccharides are water soluble polymers and may be ionic or nonionic. Microbial EPSs, containing $90 \%$ or more polysaccharides [20], could be categorized into 2 broad classes: homopolysaccharides, which are compounds of single units of monosaccharide, and heteropolysaccharides, which are composed 
of 2 or more units of monosaccharide.

EPSs are highly important to any bacterium as a defense mechanism; to prevent desiccation [20]; for adhesions by forming biofilms [21]; and in industries as gelling agents, biosurfactants, emulsifiers, viscosifiers [22], biosorbents [23], and biologically active antimicrobials, anticancer agents, and antioxidants [24].

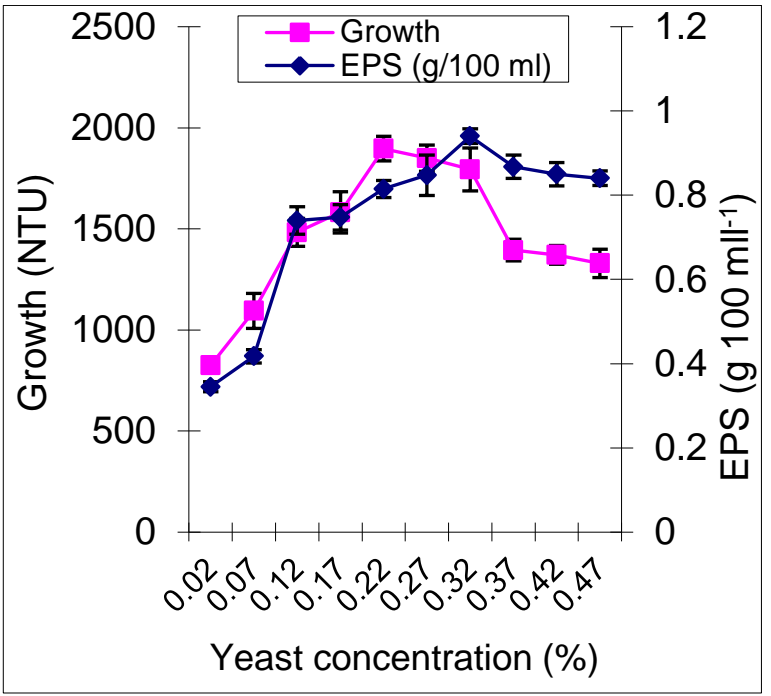

Fig. 7 Effect of different yeast extract concentrations on production of EPS and biomass by Bacillus subtilis. Data are represented by means of three replica \pm SE.

EPS is often produced at a lower temperature than is required for optimum growth [25]. It also requires higher carbon content in the medium and decreased nitrogen quantity [4] Factors that could influence the production of EPS are the composition of the medium, especially carbon and nitrogen sources, and parameters like $\mathrm{pH}$, temperature, and incubation time. The commercial value of EPS would be determined by the ease of production, the quality produced, the composition of the polysaccharide, and the mode of harvest. A huge variety of biopolymers such as polysaccharide, polyesters, and polyamides are naturally produced by microbes. They range from a viscous solution to plastic, and their physical properties are dependent on the composition and molecular weight of the polymer. The genetic manipulation of the microorganism opens up an enormous potential for the biotechnological application with tailored properties suitable for tissue engineering and drug delivery.

Among seven types of media, the basal media supported the maximal production of EPS followed by XP media while YG media supported the minimal EPS production.

In our study the production of EPS increased during the growth phase of the culture, and the period for the production was reached after 72 hours (the 3rd day) of incubation period. The maximum growth of Bacillus subtilis was reached at the 3rd day followed by stationary region through 4 th and 5th days.

Table 3. Biochemical activities of isolate no. 1.

\begin{tabular}{|c|c|}
\hline Test & Test result \\
\hline \multicolumn{2}{|l|}{ Degradation of } \\
\hline Casein & + \\
\hline Starch & + \\
\hline Gelatin & - \\
\hline Urea & + \\
\hline \multicolumn{2}{|l|}{ Enzyme activity } \\
\hline Proteolysis on egg yolk & + \\
\hline Nitrate reduction & + \\
\hline Hydrogen sulphide production & - \\
\hline Formation of indole & - \\
\hline Dihydroxy acetone production & + \\
\hline Degradation of tyrosine & - \\
\hline Degradation of citrate & - \\
\hline Degradation of propionate & - \\
\hline Degradation of phenylalanine & - \\
\hline Production of gas from glucose & - \\
\hline Catalase test & + \\
\hline Voges Proskauer test & + \\
\hline \multicolumn{2}{|l|}{ Effect of $\mathrm{NaCl}$ conc. } \\
\hline $0 \%$ & + \\
\hline $2 \%$ & + \\
\hline $5 \%$ & + \\
\hline $7 \%$ & + \\
\hline $10 \%$ & - \\
\hline \multicolumn{2}{|c|}{ Production of acid from carbohydrate } \\
\hline D- glucose & + \\
\hline L- arabinose & + \\
\hline D- xylose & + \\
\hline D- mannitol & + \\
\hline \multicolumn{2}{|l|}{ Growth at different $\mathrm{pH}$ : } \\
\hline pH 5.7 & + \\
\hline pH 6.8 & + \\
\hline \multicolumn{2}{|c|}{ Growth of different strains at different } \\
\hline \multicolumn{2}{|c|}{ temperatures } \\
\hline $15^{\circ} \mathrm{C}$ & + \\
\hline $20^{\circ} \mathrm{C}$ & + \\
\hline $25^{\circ} \mathrm{C}$ & + \\
\hline $30^{\circ} \mathrm{C}$ & + \\
\hline $35^{\circ} \mathrm{C}$ & + \\
\hline $40{ }^{\circ} \mathrm{C}$ & + \\
\hline $45^{\circ} \mathrm{C}$ & + \\
\hline $50^{\circ} \mathrm{C}$ & + \\
\hline $55^{\circ} \mathrm{C}$ & - \\
\hline
\end{tabular}


According to Decho [26] and Manca et al. [27], the largest quantity of EPS was released during stationary growth phase in laboratory culture. The results obtained on Klebsiella aerogenes in liquid media, show that, the rate of polysaccharide production was greatest during the exponential phase of growth and gradually decreased thereafter [28]. Norval [29] reported that the rate of polysaccharide synthesis in washed cell suspension by log-phase and stationary-phase cells grown in several different media was very similar. The ability to synthesize extracellular polysaccharide was lost from older cultures $(48 \mathrm{hr})$ in synthetic media and was very low in cells grown in media lacking a utilizable carbohydrate.

In the present study, the data showed that the maximum growth production by Bacillus subtilis was obtained at $\mathrm{pH} 7.0$ and then significantly decreased. The maximum production of EPS also occurred at $\mathrm{pH} 7.0$ after a slightly increase in EXP level at pH 5.0 and 6.0.

Results obtained from this study show that Bacillus subtilis was able to grow in medium supplied with nine different carbon sources which were maltose, lactose, sorbose, galactose, arabinose, xylose, sucrose, glucose and mannitol. It has been found that sucrose was the best carbon source which stimulates the maximum yield of EPS followed by mannitol. It is appeared that there is a significant increase of EPS production by sucrose comparing with all carbon sources used. At the same time there is no significant difference in production of EPS between the other carbon sources. Sucrose also supported the best growth of Bacillus subtilis which followed by glucose. Maltose and mannitol also support a good biomass production, but the minimum growth was obtained by sorbose.

Sucrose concentration at $4.5 \%$ stimulated the maximal EPS production followed by $5.0 \%$. Above this concentration EXP production was slightly decreased while the optimum growth occurred at concentration 5.5\%.

On the other hand, Gandhi et al. [30] pointed out that ratios of carbon and nitrogen sources play the most important role in cellular growth and exobiopolymer production. At $100 \mathrm{~g} \mathrm{l}^{-1}$ sucrose, it was best source for EPS production from B. licheniformis 221a, at $13.57 \mathrm{~g}^{\mathrm{EPS}} \mathrm{l}^{-1}$ of medium [31]. Sucrose, a disaccharide, upon hydrolysis produces glucose and fructose. Higher yield is obtained, since sucrose apparently acts as a precursor of EPS synthesis. As the concentration of the sugars increased above $2 \%$, the cell growth and the yield were found to decline. This is mostly due to the elevation of osmotic pressure in the cellular system, thereby causing plasmolysis, leading to cell death [32]. Various studies have been carried out to learn the effects of different carbon substrates on EPS production. A concentration of $2 \%$ maltose in the production medium was able to produce $3.5 \mathrm{~g}$ EPS $1^{-1}$ from Cordyceps jiangxiensis [33]. A maximum of $44.49 \mathrm{mg} \mathrm{l}^{-1}$ of EPS was produced from Lactobacillus fermentum when the medium was supplemented with $2 \%$ glucose and $0.5 \%$ whey protein concentrate [34]. Sugars like fructose, lactose, glucose, and sucrose were used for EPS production in Streptococcus thermophilus ST1 from skim milk, yielding $64.52 \mathrm{mg} \mathrm{l}^{-1}, 66.39 \mathrm{mg} \mathrm{l}^{-1}, 69.35 \mathrm{mg} \mathrm{l}^{-1}$, and 73.28 $\mathrm{mg}^{-1}$, respectively [35].

Various nitrogen sources were observed for their effects on EPS yield from our isolate. Organic nitrogen sources were inferred to yield a higher amount of EPS than inorganic nitrogen substrates. Yeast extract was found to produce the maximum yield of EPS by $\mathrm{KNO}_{3}$ and peptone as nitrogen sources, respectively. Meat extract, ammonium sulphate, ammonium sulphate plus yeast extract (AS + YE) supported less production of EPS. However, the other nitrogen sources as tryptone, $\mathrm{NH}_{4} \mathrm{NO}_{3}$, ammonium phosphate and ammonium oxalate supported minimum EPS production, respectively.

The highest production of biomass was reached by using $\mathrm{KNO}_{3}$ as nitrogen source followed by peptone and meat extract. Tryptone, yeast extract and $\mathrm{NH}_{4} \mathrm{NO}_{3}$ also stimulate the growth of Bacillus subtilis, respectively, but the other nitrogen sources as ammonium sulphate plus yeast extract (AS + YE), ammonium phosphate, ammonium oxalate and ammonium sulphate slightly supported the bacterial growth.

Both EPS production and growth of Bacillus subtilis was recorded at from concentration $0.02 \%$ and $0.07 \%$ to concentration $0.12 \%$ and $0.17 \%$. Then a slightly increase in EPS production occurred until the maximum amount of EPS reached at concentration $0.32 \%$, after this concentration EPS production was decreased. The optimal growth of Bacillus subtilis was occurred at concentration $0.22 \%$ of yeast extract.

It was suggested that certain essential amino acids cannot be synthesized from inorganic nitrogen components [36], because of which bacterial cells might neither fully grow nor undergo metabolism, and hence the deterioration 
of EPS yield. It was also reported that the primary role of heterotrophic bacteria is classically considered to be decomposition and mineralization of dissolved particulate organic nitrogen. This might be an obvious cause of higher production of EPS by B. subtilis. As the concentration of the nitrogen sources was increased, the growth rate was found to ascend, but the mitigation of EPS production was observed. Reports suggest that nitrogen limitation and higher amounts of carbon in the medium could yield a maximum amount of EPS. A study showed that EPS production from Rhizobium meliloti was higher when the nitrogen source was in minimal quantity. Similarly, pullulan was generated by Aureobasidium pullulans when it was grown in a medium with lesser amounts of nitrogen source.

\section{References}

[1] M. Kleerebezem, R. Van Kranenburg, R. Tuinier, I.C. Boels, P. Zoon, E. Looijesteijn, J. H. Ugenholtz, W.M. de Vos, Exopolysaccharides produced by Lactococcus lactis: from genetic engineering to improved rheological properties. Antonie Leeuwenhoek 76 (1999) 357

[2] C. Whitfield, Bacterial extracellular polysaccharides. Can. J. Microbiol. 34 (1988) 415

[3] I.W. Sutherland, Novel and established applications of microbial polysaccharides. Trends Biotechnol. 16 (1998) 41

[4] L. De Vuyst, B. Degeest, Heteropolysaccharides from lactic acid bacteria. FEMS Microbiol. Rev. 23 (1999) 153

[5] J. Cerning, Exocellular polysaccharides produced by lactic acid bacteria. FEMS Microbiol. Rev. 87 (1990) 113

[6] P. Monsan, S. Bozonnet, C. Albenne, G. Joucla, R.M. Willemot, M. Remaud-Simeon, Homopolysaccharides from lactic acid bacteria. Internatl Dairy J. 11 (2001) 675

[7] A.J. Groenwall, B.J.A. Ingelman, Manufacture of infusion and injection fluids. U. S. Patent. 2 (1948) 437

[8] W.D. Soetaert, K. Schwengers, Buchholz, E.J.Vandamme, A wide range of carbohydrate modifications by a single microorganism: Leuconostoc mesenteroides. In: S.B. Peterson, B. Svensson, S. Pederson (Eds.) Carbohydrate Bioengineering, Elsevier, Amsterdam, Vol. 10, (1995) p. 351

[9] G.R. Gibson, M.D. Roberfroid, Dietary modulation of the human colonic microbiota Introducing the concept of prebiotics. J. Nutr. 125(1995) 1401
[10] J.H. Cummings, G.T. Macfarlane, H.N. Englyst, Prebiotic digestion and fermentation. American Journal of Clinical Nutrition 73 (2001) $415 \mathrm{~S}$

[11] N. Kosaric, G.P. Cosentino, A. Wieczorek, Z. Duvnjak, The Jerusalem artichoke as an agricultural crop. Biomass 5 (1984) 1

[12] T. Tokunaga, T. Oku, N. Hosoya, Influence of chronic intake of new sweetener fructooligosaccharide (Neosugar) on growth and gastrointestinal function of the rat. J. Nutr. Sci. Vitaminol. 32 (1986) 111

[13] H. Hidaka, T. Tashiro, T. Eida, Proliferation of bifidobacteria by oligosaccharides and their useful effect on human health. Bifidobacteria Microflora 10 (1991) 65

[14] R.C. McKellar, H.W. Modler, Metabolism of fructo-oligosaccharides by Bifidobacterium spp. Appl. Microbiol. Biotechnol. 31 (1989) 537

[15] J.W. Costerton, P.S. Stewart, E.P. Greenberg, Bacterial biofilms: a common cause of persistent infections. Science 284 (1999) 1318

[16] P.H.A. Sneath, Endospore-forming Grampositive rods and cocci. In: J.G. Holt, N.R. Krieg, P.H.A. Sneath, J.T. Staley, S.T. Williams (eds) Bergey's Manual of Systematic Bacteriology. Williams and Wilkins, Baltimore (1986)

[17] R.A. Slepecky, H. E. Hemphill, The Genus Bacillus-Nonmedical. In: A. Balows, H.G. Trüper, M. Dworkin (ed) M., W. Harder, K-H Schleifer, The Prokaryotes: A Handbook on the Biology of Bacteria: Ecophysiology, vol. II, (1991) p.1769

[18] I.W. Sutherland, Bacterial exopolysaccharides. Adv. Microb. Physiol. 8 (1972)143

[18] F. Freitas, D.A. Alves, M.A.M. Reis, Advances in bacterial exopolysaccharides: from production to biotechnological applications. Trends Biotechnol. 29 (2011) 388

[19] İ. Türetgen, N.O. Şanlı Yürüdü, I. Norden, Biofilm formation comparison of the SANIPACKING cooling tower fill material against standard polypropylene fill material in a recirculating model water system. Turk. J. Biol. 36 (2012) 313

[20] P.V. Bhaskar, N.B. Bhosle, Bacterial extracellular polymeric substance carrier of heavy metals in the marine food-chain. Environ. Int. 32 (2006) 191

[21] E. İlhan Sungur, İ. Türetgen, R. Javaherdashti, Monitoring and disinfection of biofilmassociated sulfate reducing bacteria on different substrata in a simulated recirculating cooling tower system. Turk. J. Biol. 34 (2010) 389

[22] A. Poli, G. Anzelmo, B. Nicolaus, Bacterial exopolysaccharides from extreme marine habitats: production, characterization and biological activities. Mar. Drugs 8 (2010) 1779

[23] P.S.O. Martins, N.F. de Almeida, S.G.F. Leite, Application of a bacterial extracellular polymeric 
substance in heavy metal adsorption in a cocontaminated aqueous system. Braz. J. Microbiol. 39 (2008) 780

[24] C.T. Liu, F.J. Chu and C.C. Chou, Antiproliferative and anticytotoxic effects of cell fractions and exopolysaccharides from Lactobacillus casei 01. Mutat. Res. 721 (2011) 157

[25] W.F. Fett, Bacterial exopolysaccharides: their nature, regulation and role in host-pathogen interactions. Curr. Topics Bot. Res. 1 (1993) 367

[26] A.W. Decho, Microbial exopolymer secretions in ocean environments: their role(s) in food webs and marine processes. In: M. Barnes (ed) Oceanogr Marine Biology, Annual Review, Aberdeen: Aberdeen Univ Press. (1990) p. 73

[27] M.C. Manca, L. Lama, R. Improta, A. Esposito, A. Gambacorta, B. Nicolaus, Chemical composition of two exopolysaccharides from Bacillus thermoantarcticus. Appl. Environ. Microbiol. 62 (1996) 3265

[28] J.P. Duguid, J.F. Wilkinson, The influence of cultural conditions on polysaccharide production by Aerobacter aerogenes. J. Gen. Microbiol. 9 (1953) 174

[29] M. Norval, Ph.D. Thesis: Edinburgh University (1969)

[30] H.P. Gandhi, R.M. Rayand, R.M. Patel, Exopolymer production by Bacillus species. Carbohyd Polym 34 (1997) 323

[31] M. Tharek, Z. Ibrahim., S.H. Hamzah, N. Markum, A.M. Aris, F.N. Daud, M.M. Salleh, A.
Yahya, L.C. Wai, N. Khairuddin, R. Illias, M.I. Omar, K.S. Foo, E.J. Elias, and S. Bailey, Isolation, screening and characterization of soluble exopolymer-producing bacteria for enhanced oil recovery. Proceeding of Regional Postgraduate Conference on Engineering and Science (RPCES 2006), (2006) p 26, ISBN 978953-307-109-1, Johore, Malaysia, July 17-22.

[32] A. Kuntiya, P. Hanmoungjai, C. Techapun, Influence of $\mathrm{pH}$, sucrose concentration and agitation speed on exopolysaccharide production by Lactobacillus confuses TISTR 1498 using coconut water as a raw material substitute. Maejo. Int. J. Sci. Technol. 4 (2010) 318

[33] J.H. Xiao, D.X. Chen, J.W. Liu, Optimization of submerged culture requirements for the production of mycelial growth and exopolysaccharide by Cordyceps jiangxiensis JXPJ 0109. J. Appl. Microbiol. 96 (2004) 1105

[34] Y. Zhang, S. Li, C. Zhang, Growth and exopolysaccharide production by Lactobacillus fermentum F6 in skim milk. Afr. J. Biotechnol. 10 (2011) 2080

[35] T. Zhang, C. Zhang, S. Li, Growth and exopolysaccharide production by Streptococcus thermophilus ST1 in skim milk Braz. J. Microbiol. 42 (2011) 1470

[36] C.Y. Wu, Z.C. Liang, C.P. Lu, Effect of carbon and nitrogen sources on the production and carbohydrate composition of exopolysaccharide by submerged culture of Pleurotus citrinopileatus. J. Food Drug Anal. 16 (2008) 61
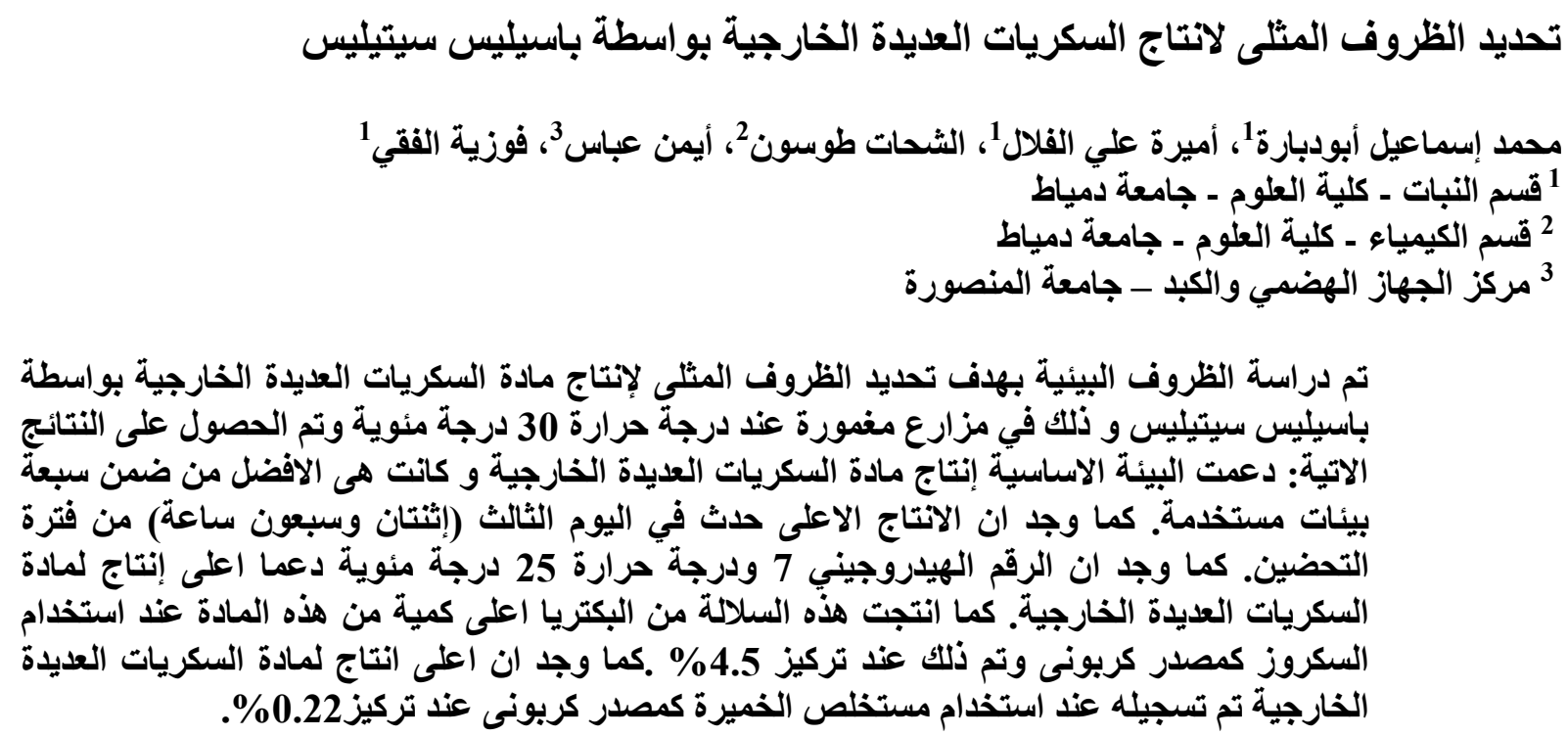